Article

\title{
Energetic and Economic Analyses of an LCPV/T Solar Hybrid Plant for a Sports Center Building in Mexico
}

\author{
Iván Acosta-Pazmiño ${ }^{1}\left(\mathbb{D}\right.$, Carlos Rivera-Solorio ${ }^{1}\left[\right.$ and Miguel Gijón-Rivera ${ }^{2, *}$ (]) \\ 1 Tecnologico de Monterrey, Escuela de Ingeniería y Ciencias, Ave. Eugenio Garza Sada 2501, \\ Monterrey 64849, N.L., Mexico; ivan.acosta.2015@ieee.org (I.A.-P.); rivera.carlos@tec.mx (C.R.-S.) \\ 2 Tecnologico de Monterrey, Escuela de Ingeniería y Ciencias, Vía Atlixcáyotl 5718, \\ Reserva Territorial Atlixcáyotl, Puebla 72453, Pue., Mexico \\ * Correspondence: miguel.gijon@tec.mx
}

Received: 24 September 2020; Accepted: 28 October 2020; Published: 30 October 2020

\begin{abstract}
This study presents a techno-economic performance evaluation of a hybrid low-concentrating photovoltaic/thermal (LCPV/T) plant, which operates in a student sports and wellness center building situated at a university campus in Mexico. The solar plant comprises $144 \mathrm{LCPV} / \mathrm{T}$ collectors based on a hybridized version of a local parabolic trough technology. Dynamic thermal and electrical performance analyses were performed in the TRNSYS simulation studio. The results showed that the solar field could cover up to $72 \%$ of the hot water demand of the building during the summer season and $24 \%$ during the winter season. The hybrid system could annually save 7185 USD, accounting for heat (natural gas boiler) and electricity generation. However, the payback time was of 19.23 years, which was mainly attributed to a reduced natural gas price in Monterrey, Mexico. A new approach to evaluating the equivalent levelized cost of heat $\left(L C O H_{e q}\right)$, is proposed. This results in an $\mathrm{LCOH}_{e q}$ of $0.065 \mathrm{USD} / \mathrm{kWh}$, which is nearly equivalent to the $\mathrm{LCOH}$ of a natural gas-fired boiler $(0.067 \mathrm{USD} / \mathrm{kWh})$. Finally, the hybrid plant could achieve a specific $\mathrm{CO}_{2} \mathrm{e}$ emission reduction of $77.87 \mathrm{~kg} \mathrm{CO}_{2} \mathrm{e}$ per square meter of the required installation area.
\end{abstract}

Keywords: hybrid solar; PV/T; buildings; dynamic simulation

\section{Introduction}

Globally, buildings account for almost half of the final energy consumption, which is mainly associated with fossil fuels. Solar energy is a vast and renewable primary energy source that can effectively and efficiently produce the electrical and thermal energies consumed by buildings. Hybrid solar photovoltaic/thermal (PV/T) collectors can simultaneously produce thermal and electrical energies, thereby reducing the area required for installation in comparison to stand-alone photovoltaics and thermal collectors. This characteristic is particularly convenient for buildings because of the limited roof area and energy consumption profile (both thermal and electrical).

Several studies were conducted to evaluate the performance of PV/T plants considering their applications in buildings. For instance, Sotehi et al. [1] presented a theoretical approach of a net zero energy building using hybrid PV/T solar collectors in Ouargla City. They found that the PV/T collectors can cover both the hot water and the electrical annual demand of the building.

Fuentes et al. [2] conducted an experimental evaluation between hybrid PV/T and simple PV systems intended for building integrated PV systems. They concluded that the PV/T system did not achieve higher electrical efficiencies than those of a simple PV, as was expected, because of the active cooling mechanism. Yang et al. [3] simulated a low-concentrating PV/T system for hot water, power, and cooling production. The hybrid system could generate hot water (between 45 and $90^{\circ} \mathrm{C}$ ), with an 
electrical efficiency of $10 \%$, and a coefficient of performance (COP) above 0.5 for the lithium-bromide absorption chiller.

Herrando et al. [4] evaluated a 1.68 MWp solar combined cooling, heating, and power system based on hybrid PV/T collectors for a University Campus in Bari, Italy. The hybrid plant could meet $20.9 \%, 55.1 \%$, and $16.3 \%$ of the space-heating, cooling, and electrical demands of the campus. The payback time (PBT) obtained was 16.7 years. The energy yield of a solar-based combined heat and power system (S-CHP) based on PV/T collectors was observed to be higher than those of other conventional solar systems including PV panels and evacuated tube collectors, in a sports center building in Italy. The PV/T plant could cover $82.3 \%$ and $51.3 \%$ of the electricity and thermal demand of the building, respectively [5].

The integration of a PV/T plant into a smart building in Sweden was theoretically evaluated and optimized by Behzadi et al. [6]. The PV/T system achieved a cost reduction of 16.7 EUR/MWh in electricity and 7.7 EUR/MWh in heat. Brottier et al. [7] studied the thermal performances of small-sized PV/T systems for residential buildings in Western Europe. They observed that the PV/T technology was well suited for residential applications owing to its potential to achieve a high solar fraction regarding hot water consumption. PV/T collectors, as parts of a trigeneration system for zero energy buildings in Moscow, Stuttgart, and Dubai, were theoretically evaluated by Braun et al. [8]. They observed that $\mathrm{PV} / \mathrm{T}$ systems offered an economic advantage in office buildings where heating, cooling, and electricity were needed. They further identified that in countries with a lack of incentives for renewable energy projects, specific energy generation costs heavily depended on the electricity tariffs of the location. Additionally, optimization methods to adapt to the fluctuations of the dynamic loads in buildings and to reduce the impact in PV/T collectors were developed in the literature [9].

The combination of heat pumps and PV/T collectors for heat and power generation in buildings could be one of the widely studied applications of hybrid solar systems in the literature. Obalanlege et al. [10] evaluated the effect of solar irradiation intensity, tank volume, and solar field flow rate on the performance of a hybrid PV/T and heat pump system in residential homes. They indicated that the design of such systems should consider geographic location because of the variability in meteorological parameters. Amo et al. [11] observed that the performance of a water-water solar-assisted heat pump in a university building located at Zaragoza (Spain) could be enhanced upon the integration of PV/T collectors and seasonal storage. Moreover, the electricity produced by the PV/T collectors could cover the heat pump consumption. Besides, PVT collectors are feasible and rewarding solutions for off-grid applications [12], indicating the versatility of the PV/T technology. Finally, the PV/T collector technology can be easily integrated into buildings by following different installation alternatives that can harmonically coexist with the architecture of the building and natural elements, as studied in [13].

The literature review shows that the techno-economic performance of PV/T systems strongly depends on the local parameters and conditions including meteorological variables, energy tariffs, and local technology availability. Furthermore, most studies on PV/T plants for building applications have been performed mainly in Europe and Asia, considering non-concentrating PV/T collectors, as most of the hybrid solar technologies are being developed and produced in these regions only. There is a lack of information and knowledge regarding the potential of PV/T technologies in Latin America although the expected maximum increase in the energy consumption of buildings is in emerging economies [14]. One of the main facilitators for the deployment of renewable-energy-based systems is the availability of local technologies. Unfortunately, in developing countries like Mexico, the lack of state-of-the-art hybrid solar technology hampers the adoption of clean energy systems, which could be used to efficiently harvest the vast solar resource available in these territories. Nevertheless, of the top 10 solar thermal suppliers/manufacturers in the world, two are from Mexico [15]. This indicates a great opportunity to develop the local PV/T technology in these countries, given the fact that most market-available PV/T systems in these countries are hybridized solar thermal collectors or PV panels. 
This study presents a techno-economic performance evaluation of an LCPV/T plant for a student sport and wellness center building situated in Monterrey, Mexico. The proposed collectors are hybridized versions of a local parabolic trough technology. The plant was dynamically evaluated under the TRNSYS 18 environment (Thermal Energy System Specialists, Madison, WI, USA), by using a component (type 55F) modified by the authors to include the incidence-angle effect on the hybrid collector. The thermal and electrical energy yields of the plant are evaluated, along with other operational variables, including the thermal and electrical peak power and temperature profiles. An economic evaluation of the solar hybrid plant is conducted by estimating the following: final cost of the system, lifecycle costs due to reduced fuel and electricity consumption, and PBT of the investment. Additionally, the levelized cost of heat and electricity is determined and compared with that of the conventional energy production (natural gas boiler and electricity consumption). Moreover, the environmental impact due to the displacement of natural gas and electricity is evaluated in terms of $\mathrm{CO}_{2}$ e emission reduction.

This article contributes to the field of solar technologies by presenting the techno-economic performance of a novel locally developed LCPV/T collector in a Latin American country, where no previous studies were presented in the literature. The hybrid technology hereby studied was designed, built, characterized, and tested by our research group with a collaboration with a local manufacturer. The results of this paper give valuable insights, first to the local manufacturer to evaluate a possible hybridization of its solar thermal technology, and second to local policymakers. This can lead to the development of currently lacking local incentives and public policies, and to allocate investments that may encourage the adoption of this technology in Mexico, as it has been successfully adopted in Europe and Asia.

\section{Materials and Methods}

\subsection{Transient Energy Modeling}

The LCPV/T plant was evaluated under the TRNSYS software environment. The hybrid plant comprised 144 hybrid collectors, i.e., 12 rows each with 12 collectors, which covered a total roof area of $1281 \mathrm{~m}^{2}$. The hybrid collectors were based on a small-sized parabolic trough with a triangular receptor that had c-Si back-contact solar cells attached on the receiver sides that collected concentrated sunlight. The hot water produced by the plant will be used to cover the following part of the thermal demands of the building, i.e., domestic hot water (DHW), and pool heating. The electrical production, however, was only considered an additional energy input to the building electricity consumption, which will be accounted for by monetary and environmental gains. A simplified process diagram of the simulated system is shown in Figure 1. Energy plus weather files were used to simulate a typical meteorological year for the studied location.

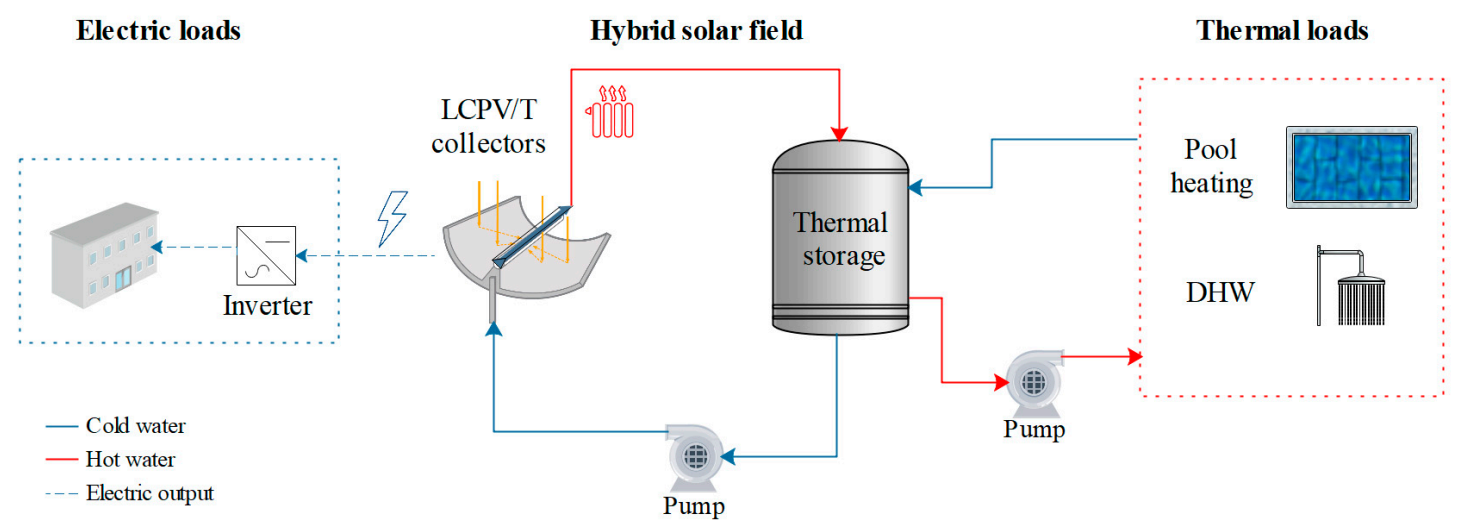

Figure 1. Configuration of the hybrid solar heat and power system (Source: Author's own conception). 
The hybrid collector was modeled using a modified version of Type 50f, which considered an incidence-angle modifier of the system. Type 50f is a component developed to model concentrating hybrid solar collectors for cases wherein the thermal losses depend on the wind velocity and collector temperature. As we proposed in this study, Type $50 \mathrm{f}$ was modified to include the incidence-angle modifier of the system, $K(\theta)$, to model the concentrating collector. Moreover, the thermal performance parameters, including the contact resistance $R_{c}$ between PV cells and absorber, heat-transfer coefficient $U_{A b s_{F l u i d}}$ between the duct and heat-transfer fluid, and heat-transfer coefficient $U_{L}$ for the thermal losses of the collector, were obtained using a one-dimensional steady-state model of the hybrid collector; the model was previously developed and fully validated on experimental data by [16]. The thermal and electric performances of the hybrid LCPV/T collector were calculated using the principal Equations (1)-(6). The most relevant inputs of the simulation model are presented in Table 1.

Useful thermal output [17]

$$
\dot{Q_{u}}=F_{R} A_{a}\left[S-\frac{A_{r}}{A_{a}} U_{L}\left(T_{i}-T_{a m b}\right)\right]
$$

Collector heat removal factor [18]

$$
F_{R}=\frac{\dot{m} c p}{U_{L}}\left[1-\exp \left(-U_{L} F^{\prime} / \dot{m} c p\right)\right]
$$

Collector efficiency factor [17]

$$
F^{\prime}=\left(1+\frac{U_{L}}{U_{A b s_{\text {Fluid }}}}\right)
$$

Heat loss coefficient [17]

$$
U_{L}=\frac{Q_{\text {Loss }}}{A_{r}\left(T_{r}-T_{a m b}\right)}
$$

Incidence-angle modifier [19]

$$
K(\theta)=1-b_{o}\left(\frac{1}{\cos (\theta)}-1\right)
$$

Electric output [18]

$$
P_{e}=\frac{A_{a} S \eta_{P V}}{\alpha} \sqrt{\left\{1-\frac{\eta_{P V_{r}} K_{T}}{\eta_{P V}}\left[F_{R}\left(T_{i}-T_{a}\right)+\frac{S}{U_{L}}\left(1-F_{R}\right)\right]\right\}}
$$

where $T_{i}$ denotes the intermediate temperature, which is the average of the inlet and outlet water temperatures. The parameter $b_{0}$, which shapes the curvature of the function presented in Equation (5), was taken from [20].

The total annual heat and electricity productions of the hybrid solar plant are calculated using the following relations.

Thermal energy yield

$$
Q_{u}=\int \dot{Q_{u}} d t
$$

Electrical energy yield

$$
E_{e l}=\int P_{e} d t
$$

The main assumptions and considerations for modeling the proposed hybrid solar collector under steady-state conditions are thermodynamic equilibrium, uniform distribution of concentrated solar radiation in the solar cells, constant surface heat flux, and constant material properties. However, 
dynamic modeling considers that the PV modules work at the maximum power point and use a constant daily thermal load profile throughout the year.

Table 1. Inputs of the simulation model (Source: Author's own calculation, [21,22]).

\begin{tabular}{lc}
\hline \multicolumn{1}{c}{ Feature } & Value \\
\hline Process and solar field & $30 \mathrm{~m}^{3}$ \\
\hline Daily hot water demand & $55^{\circ} \mathrm{C}$ \\
\hline Temperature demand & 16.6 \\
\hline Solar field azimuth & $30 \mathrm{~m}^{3}$ \\
\hline Thermal storage capacity & $94.4 \mathrm{~kW}$ \\
\hline Heat demand & 0.601 \\
\hline Hybrid collector & 14.8 \\
\hline Optical efficiency, $\eta_{0 A}$ & $3838 \mathrm{~W} / \mathrm{m}^{2} \mathrm{~K}$ \\
\hline Concentration ratio & $2.77 \mathrm{~W} / \mathrm{m}^{2} \mathrm{~K}$ \\
\hline Internal heat transfer coefficient, $U_{A b s F l u i d}$ & $0.33 \% / \mathrm{K}$ \\
\hline Heat loss coefficient, $U_{L}$ & \\
\hline Temperature coefficient, $K_{T}$ & $0.011 \mathrm{USD} / \mathrm{kWh}$ \\
\hline Energy prices & $0.064 \mathrm{USD} / \mathrm{kWh}$ \\
\hline Natural gas, $C_{f}$ &
\end{tabular}

\subsection{Economic and Environmental Analyses}

The first year monetary savings due to the onsite generation of energy, both thermal $\left(Q_{L C P V T}\right)$ and electrical $\left(E_{L C P V T}\right)$, were calculated using Equations (9)-(14). For the thermal part, the calculation was based on obtaining the amount of fuel $\left(F_{V}\right)$ needed to produce the same amount of heat that the hybrid solar plant generates. The efficiency considered for the fuel-fired boiler was $\eta_{b}=60 \%$, which is the average efficiency of a low-load natural gas boiler [23]. To calculate the monetary savings $\left(C_{f}\right)$ associated with the displacement of natural gas, the local price $(F P)$ of natural gas was considered (see Table 1 ). For electricity generation savings $\left(C_{E}\right)$, the average efficiency of DC-AC conversion $\left(\eta_{e}=95 \%\right)$ and local tariff $(E P)$ for commercial electricity service were considered. The total annual cost savings $\left(C_{S}\right)$ were calculated using Equation (14). The operational and maintenance cost $\left(C_{O \& M}\right)$ of the solar hybrid plant was considered to be $10 \%$ of the total costs of the components.

$$
\begin{gathered}
Q_{f}=\frac{Q_{L C P V T}}{\eta_{b}} \\
F_{V}=\frac{Q_{f}}{\left(C_{L H V f}\right)} \\
E=E_{L C P V T} \times \eta_{e} \\
C_{f}=F P \times Q_{f} \\
C_{E}=E P \times E \\
C_{S}=C_{F}+C_{E}-C_{O \& M}
\end{gathered}
$$

The total hybrid plant cost $\left(C_{o}\right)$ was computed using Equation (15) [24]. The term $C_{A}$ corresponds to the area dependent costs (parabolic trough collectors, hybrid receivers, hydraulic system, storage tank, and installation costs), while $C_{I}$ resembles the costs that are independent of the area of the solar 
plant (pumping controller). The relations presented in Table 2 were used to estimate the costs of the components (parabolic trough collectors, storage tank, and hydraulic system), which were obtained from a local solar thermal retailer.

$$
C_{0}=C_{A} A_{L C P V T}+C_{I}
$$

The economic performance of the solar hybrid plant was evaluated using the parameters, namely, PBT and life cycle cost (LCC). PBT is the time required for the cumulative savings to match the total investment. $L C C$ is the integration of all the costs associated with the installation of a plant during its lifetime considering the time value of money $[24,25]$. The PBT and LCC of the plant were calculated considering an average inflation rate $i_{F}$ of $10 \%$ (average inflation rates of natural gas and electricity tariffs in Mexico), a local discount rate (d) of 5\% (average from 2005 to 2020 [26]), and a plant lifespan of 25 years [27]. The cash flow for each year was independently calculated for the fuel and electricity cost savings, taking into account the time value of money. Both the economic parameters of the hybrid plant were calculated using Equations (16) and (17) [24]. Additionally, the energetics price ratio $C_{e} / C_{f}$, which represents the quotient between the electricity price (USD/kWh) and natural gas price (USD/kWh), was used to perform a sensitivity analysis of the PBT and LCC of the plant. This allows to extend the possible economic performance of the plant considering different energetics prices in Mexico.

$$
\begin{gathered}
P B T=\frac{\ln \left[\frac{C_{0}\left(i_{F}-d\right)}{C_{s}}+1\right]}{\ln \left(\frac{1+i_{F}}{1+d}\right)} \\
L C C=\frac{C_{S}}{d-i_{F}}\left[1-\left(\frac{1+i_{F}}{1+d}\right)^{n}\right]-C_{0}
\end{gathered}
$$

Table 2. Cost breakdown of the LCPV/T plant.

\begin{tabular}{ll}
\hline \multicolumn{1}{c}{ Component } & \multicolumn{1}{c}{ Cost } \\
\hline Parabolic trough collectors ${ }^{1}$, USD (Source: local retailer) & $230 \cdot A_{L C P V T}$ \\
\hline Hybrid receiver, USD & $0.2 \cdot C_{L C P V T}$ \\
\hline Storage tank, USD (Source: local retailer) & $0.75 \cdot V_{T}(l)+675$ \\
\hline Inverter, USD/kW [28] & 238 \\
\hline Hydraulic system, USD (Source: local retailer) & $48.6 \cdot A_{L C P V T}$ \\
\hline Controller, USD (Source: local retailer) & 558 \\
\hline Installation cost, USD [28] & $0.2 \cdot$ Total component cos t \\
\hline Annual O\&M cost, USD [28] & $0.02 \cdot$ Total component cost \\
\hline
\end{tabular}

The levelized cost of energy is the net present value of the unit-cost of energy over the plant lifetime [29]. This parameter was calculated considering two approaches. The first was the approach presented by Wang et al. [5] for the equivalent levelized cost of electricity $\left(L C O E_{e q}\right)$. The second one is a self-proposed method for determining the equivalent levelized cost of heat $\left(\mathrm{LCOH}_{e q}\right)$. The scope was to compare both the methodologies for analyzing its outcomes. The $\mathrm{LCOE}_{\mathrm{eq}}$ value was calculated using Equation (18), considering the following assumptions:

- The term $E_{e q}$ denotes the annual equivalent electricity produced by the hybrid plant considering the conversion factor from heat to electricity to be 0.55 [5];

- A commercial electricity price inflation rate $i_{\text {elect }}$ of $8 \%$, (average in Mexico [22]);

- A local discount rate $d$ of $5 \%$ (reported by the National Bank of Mexico);

- An electricity production annual derate $D$ of $1 \%$.

The $\mathrm{LCOH}_{e q}$ value was calculated using Equation (19) with the following assumptions: 
- $\quad$ The term $Q_{e q}$ represents the annual equivalent heat produced by the hybrid plant considering the conversion factor from electricity to heat to be 1 , which resembles the efficiency of an electric resistance (ER) water heater [30];

- A natural gas inflation rate $i_{\text {fuel }}$ of $12 \%$ (average in Mexico [31]);

- A local discount rate $d$ of $5 \%$ (reported by the National Bank of Mexico);

- A thermal energy production annual derate $D$ of $1 \%$.

The initial investment $C_{0}$ remains the same for both the parameters, as the systems are intrinsically connected and their operations depend on each other.

Additionally, the levelized cost of heat ( $\mathrm{LCOH}$ ) and levelized cost of electricity (LCOE) values for conventional heat and power generation are calculated and compared with the values obtained for the hybrid plant. For the conventional natural gas boiler, an initial investment of 29,000 USD, annual maintenance cost of $10 \%$ from the operational cost of the boiler, and annual derate of energy (D) production of $2 \%$ were considered [23]. The operational cost of the boiler was calculated using Equations (9) and (10) considering the price of natural gas. For electricity consumption, no initial investment cost and an annual derate $D$ of $1 \%$ are considered.

$$
\begin{aligned}
\operatorname{LCOE}_{e q} & =\frac{C_{0}+\sum_{i=1}^{t} C_{O \& M}\left(1+i_{\text {elect }}\right)^{i-1}(1+d)^{-i}}{\sum_{i=1}^{t} E_{e q}(1+D)^{-i}} \\
L C O H_{e q} & =\frac{C_{0}+\sum_{i=1}^{t} C_{O \& M}\left(1+i_{\text {fuel }}\right)^{i-1}(1+d)^{-i}}{\sum_{i=1}^{t} Q_{e q}(1+D)^{-i}}
\end{aligned}
$$

Finally, to assess the $\mathrm{CO}_{2} \mathrm{e}$ emission abatement potential of the proposed plant, the local emission factors for natural gas combustion and electricity generation were considered. Emission factors of 0.2 and $0.45 \mathrm{kgCO}_{2} \mathrm{e} / \mathrm{kWh}$ were considered for natural gas combustion and electricity generation, respectively [32]. The total fuel energy $Q_{F}$ (see Equation (9)) was used to calculate the $\mathrm{CO}_{2} \mathrm{e}$ emissions due to natural gas combustion, and the total electricity production $E$ (see Equation (11)) was used to calculate the $\mathrm{CO}_{2}$ e emissions related to power generation.

\section{Results and Discussion}

The results presented in this section must be interpreted considering the following limitations. The LCPV/T technology evaluated in this study corresponds to a particular design based on a small-sized parabolic trough which receptor has been replaced for a triangular duct with c-Si solar cells in the sides that receive concentrated direct normal irradiance (DNI). The proposed plant was dynamically evaluated through simulation considering the meteorological data of Monterrey, Mexico. This should be decided whether the study is meant to be further extended to other locations, as this could affect the overall performance of the hybrid plant.

Additionally, the economic performance of the hybrid solar plant takes into account several geographically dependent assumptions, such as the average inflation rate of fuel and electricity prices, discount rate, and technology and installation costs, in Mexico. These parameters directly affect the metrics chosen to evaluate the economic performance of the plant. Hence, these assumptions should be revised if the methodology presented in this study is meant to be used to evaluate a hybrid solar system in different locations under intrinsically different conditions (economic and meteorological).

\subsection{Technical Performance}

The monthly thermal and electric yields and the solar fraction of the hybrid LCPV/T plant are shown in Figure 2. Evidently, the proposed solar plant can achieve a solar fraction as high as $72 \%$ during the summer season. Conversely, during the winter, the hybrid plant supplied $24 \%$ of the building's hot water demand, which is higher in the winter season because of the reduced temperature 
of the mains water. The term $\mathrm{Q}$ load represents the total hot water demand for a specified period (monthly or annually). The term $\mathrm{Q}$ useful denotes the thermal energy produced by the hybrid solar plant that can be consumed by the building. The term $Q$ aux denotes the heat produced by the auxiliary natural gas-fired boiler to cover the total hot water demand of the building when needed. The term $\mathrm{E}$ useful denotes the electricity produced by the hybrid plant, and it (on average) represents nearly $18 \%$ of the heat production of the system.

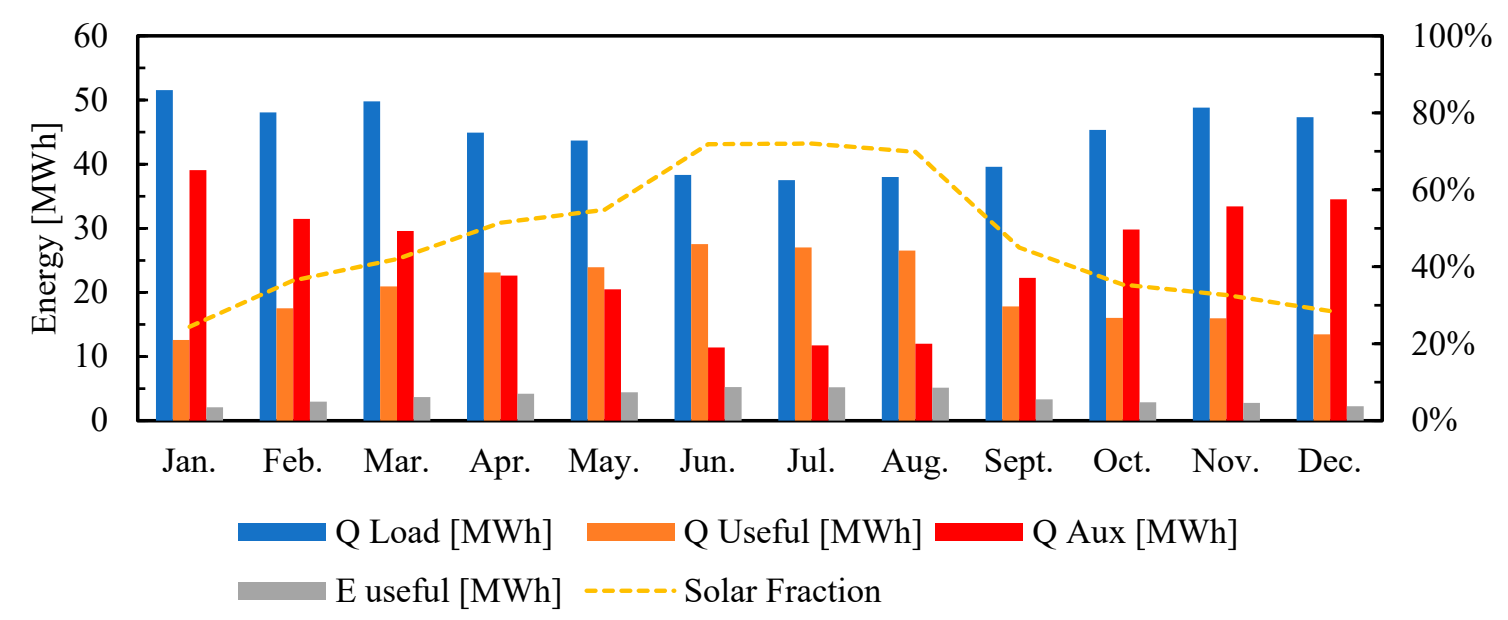

Figure 2. Monthly thermal (Q Useful) and electrical (E useful) yields of the solar hybrid plant, thermal demand (Q Load), auxiliary heat (QAux), and solar fraction (Source: Author's own calculation).

Figure 3 shows the annual energy yield of the solar field. The hybrid plant produced $47 \%$ of the annual hot water demand of the studied building. Moreover, additional $44 \mathrm{MWh}$ electricity was produced. This represents an important gain that will reduce the grid electricity consumption of the building, hence resulting in additional monetary savings and reduced $\mathrm{CO}_{2} \mathrm{e}$ emissions, as detailed in the next section. Considering the total area required for the installation of the hybrid plant, the specific thermal and electric productions achieved by the hybrid plant are 189.15 and $34.34 \mathrm{kWh} / \mathrm{m}^{2}$, respectively.

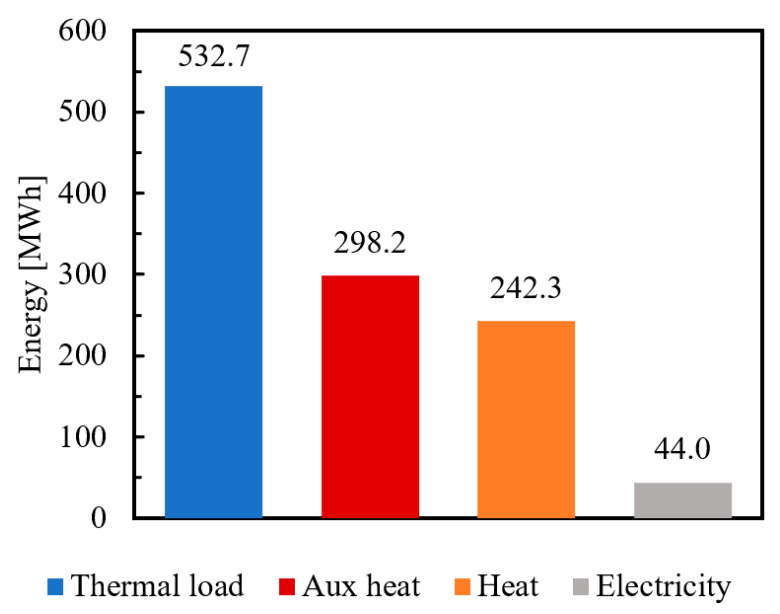

Figure 3. Annual energy yield of the hybrid plant and auxiliary system (Source: Author own calculation).

Regarding the hot water temperature produced by the solar hybrid field, the dynamic temperatures of the hybrid plant for the typical summer (23-29 July) and winter (24-30 December) weeks are shown in Figure 4. The maximum water outlet temperature of the hybrid plant during the summer weeks can reach up to $5^{\circ} \mathrm{C}$, while it is $\sim 38{ }^{\circ} \mathrm{C}$ during the winter weeks. The variation in the water outlet temperature between seasons is attributed to, apart from the intrinsic dependence on meteorological 
parameters including DNI and ambient temperature, the increase in the thermal demand of the building. As shown in Figure 5, the heat demand of the building during the winter season reaches $155.4 \mathrm{~kW}$, which is $48.9 \%$ higher than the hot water consumption during the summer $(104.4 \mathrm{~kW})$. As shown in Figure 4, the maximum solar cell temperatures recorded in the winter and summer were $48.3^{\circ} \mathrm{C}$ and $70.8^{\circ} \mathrm{C}$, respectively.

A high thermal storage capacity ensures that the water outlet temperatures from the solar field remain relatively low, even during high solar resource days. This is particularly important to keep the temperature of the hybrid collectors sufficiently low to preserve electricity production. The physics of LCPV/T collectors, such as the one evaluated in this study, indicates that the electric and thermal systems of the collector are thermally coupled. This means that an increase in the receptor temperature will raise the temperature in the PV module, hence reducing the solar energy to electricity conversion.

Another relevant operational characteristic that helps in maintaining the temperature of the hybrid receptor within acceptable ranges is a constant hot water demand, which is common in sport and wellness buildings, where the hot water demand is relatively constant throughout the year, owing to the consumption of hot water for pool heating, showers, and faucets. Nevertheless, during the summer season, another design and operational alternatives should be addressed to maintain the temperature of the PV cells within acceptable ranges. This will result in an increase in the electricity production, extending the lifetimes of the PV modules. The design improvements that could be addressed are as follows: (1) the spectral splitting technology to decouple the PV modules from the heat production system, and (2) using suspended nanoparticle fluids to increase the heat transfer between the solar cells and heat-transfer fluid.

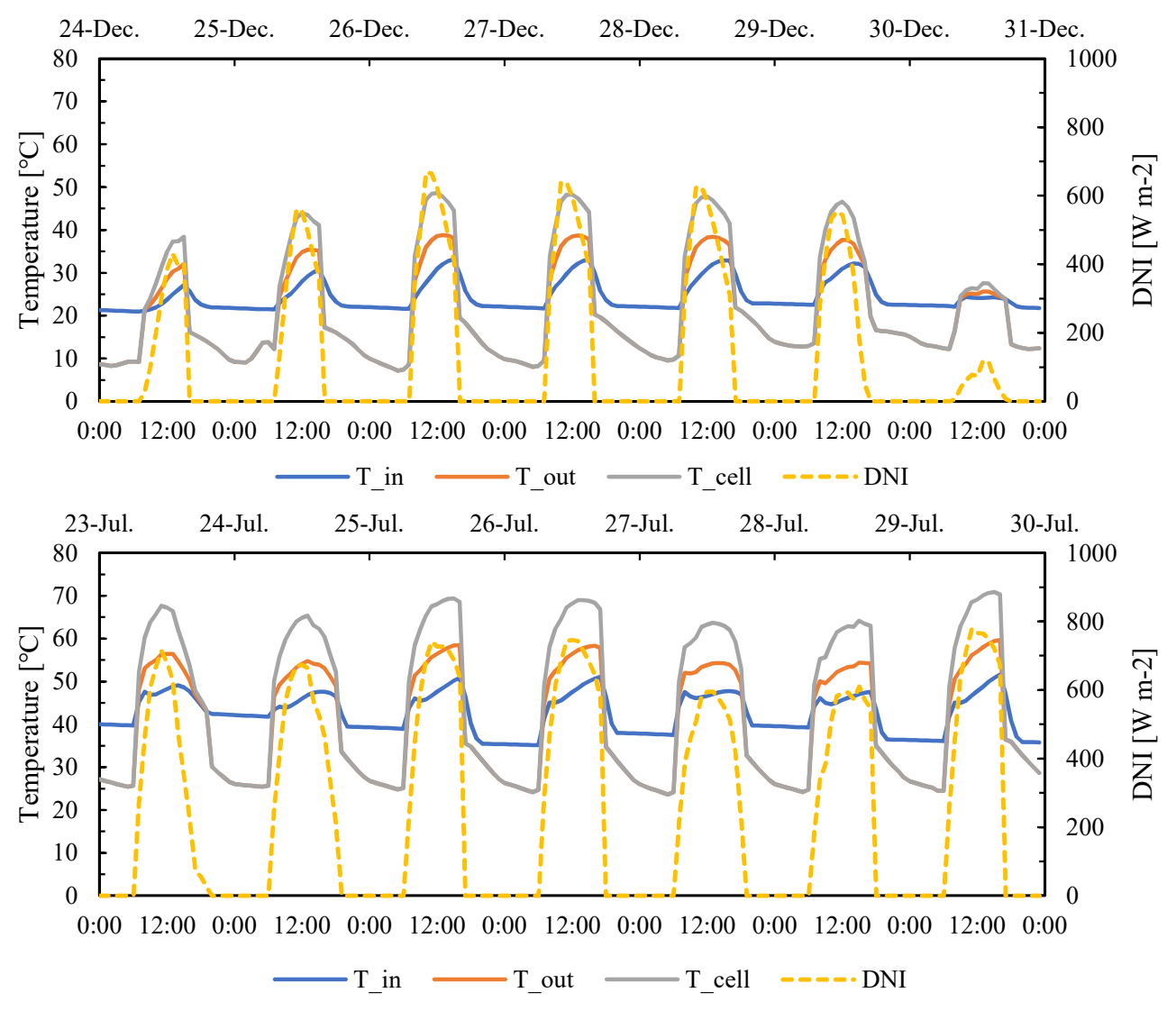

Figure 4. Temperature profile of the LCPV/T plant and DNI during the typical weeks of winter (top) and summer (bottom) (Source: Author own calculation). 

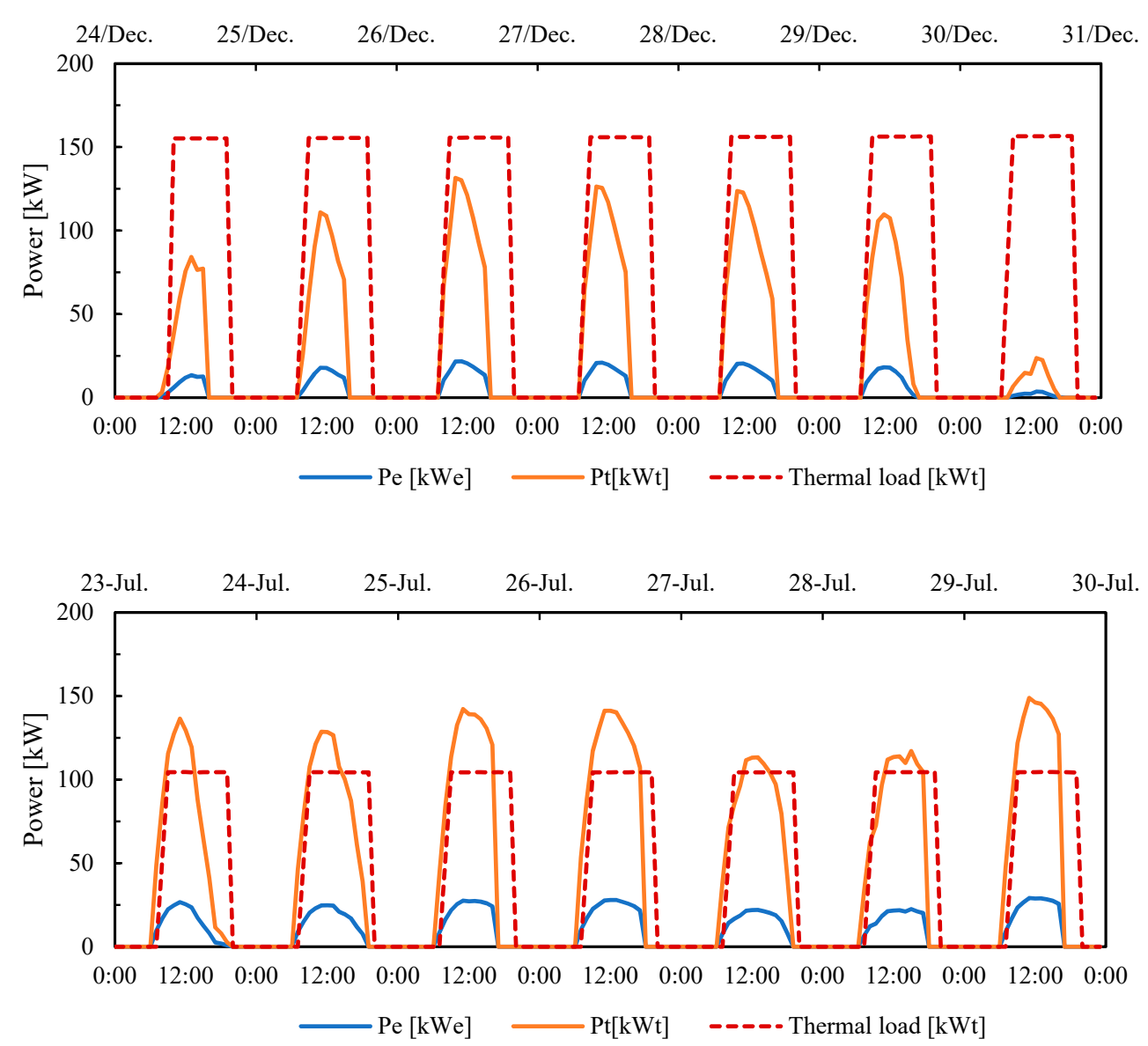

Figure 5. Thermal $(\mathrm{Pt})$ and electrical $(\mathrm{Pe})$ peak powers during the typical weeks of winters (top) and summers (bottom) (Source: Author own calculation).

From the operational perspective, the additional heat produced in the summer season can be used to drive an absorption chiller to reduce the cooling demand of the building, as presented in [29]. Nevertheless, this will imply an increased initial investment, which must be included in the economic performance assessment. Another alternative to reduce the temperature of the PV cells is to defocus the parabolic trough concentrator when the thermal demand is not sufficiently high to maintain the temperature of the solar cells within acceptable limits. However, this will entail a reduction in the energy production of the hybrid plant by reducing its availability or capacity factor.

Finally, as shown in Figure 5, the highest recorded values of the thermal and electrical powers during a typical summer day were 148.9 and $29.1 \mathrm{~kW}$, respectively. For the winter season, the thermal and electrical peak values obtained were 131.5 and $21.79 \mathrm{~kW}$, respectively.

\subsection{Economic and Environmental Performances}

The total initial cost of the hybrid plant was estimated to be 210,889 USD, considering a fraction of 0.2 from the cost of the parabolic trough reflector as the cost of the hybrid receptor. The total cost of the hybridized parabolic trough collectors was 123,206 USD, which represents an individual collector cost of 855.6 USD. This results in a total hybrid receptor cost of 142 USD per collector, which is a reference that the manufacturer can consider for establishing the final cost of the hybrid parabolic trough to achieve the economic parameters presented in this study.

If the total installation cost (workforce, materials, and inverters) of the solar hybrid plant is considered (35,055 USD), and knowing that each hybrid receptor has a 245 Wp PV module capacity, the specific electric capacity cost becomes $1.78 \mathrm{USD} / \mathrm{W}$. If the total installation cost of the hybrid plant 
is replaced by only the installation costs of the hybrid receptors (workforce, materials, and inverters), the specific electric capacity cost reaches $0.90 \mathrm{USD} / \mathrm{W}$. The installation cost of the hybrid receptor is considered to be $20 \%$ of the total cost of the PV/T receivers.

Both the considerations have been mentioned because the former can represent the case wherein a completely new solar plant, based on hybridized parabolic troughs, is to be installed, as in the case of this study, while the latter resembles the case wherein an existing solar thermal plant, based on the local parabolic trough technology, is to be hybridized by replacing the solar thermal receivers with $\mathrm{PV} / \mathrm{T}$ receptors.

From Figure 6, we can see the following: the total cost of the hybrid collectors represents $59 \%$ of the initial investment; the balance of system components (tank, hydraulic system, inverters, and storage tank) represents $24 \%$ of the downpayment; the installation cost has $17 \%$ share in the total cost. Additionally, the hybridization of the local parabolic trough technology represents $13 \%$ of the total initial investment of the solar plant.

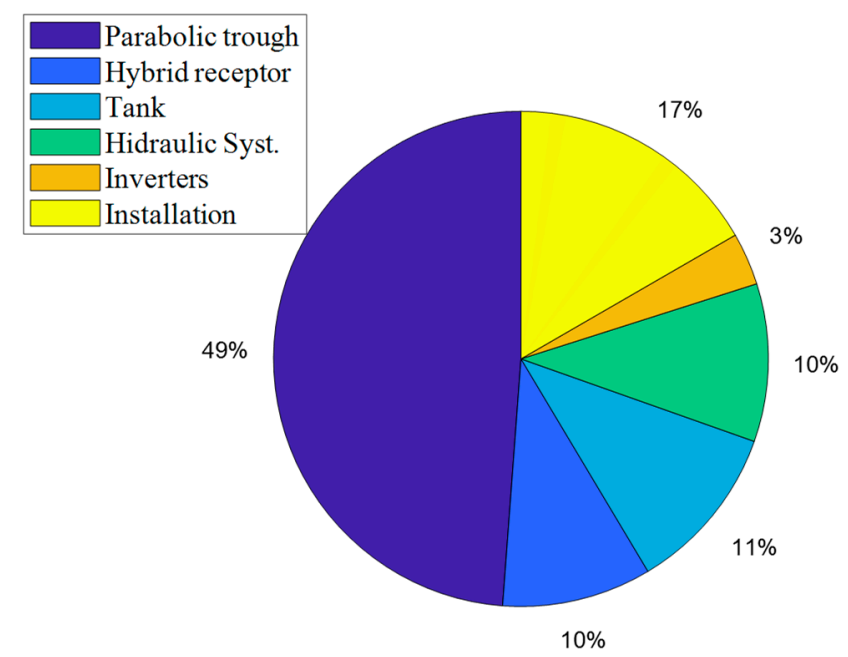

Figure 6. Breakdown of the investment costs for the hybrid solar plant (Source: Author's own calculation).

The economic performances of the hybrid plant and conventional heat and power generation, respectively, are presented in Table 3. The electricity price to natural gas price ratio obtained is 5.68, which clearly shows a remarkably low price of natural gas, despite the fact that electricity tariff in Monterrey is lower than those in other regions in Mexico. This price ratio is $16.4 \%$ greater than the highest one (i.e., 4.88), which was reported by [28] (Italy). Figure 7 plots the PBT and annual savings of the hybrid plant as a function of the energetics price ratio $C_{e} / C_{f}$. Notably, a better economic performance of the hybrid plant in terms of $P B T$ and life cycle savings is achieved as the energetics price ratio approaches one. A PBT lower than 10 years can be achieved when the energetics ratio is less than 2, with that too maintaining a relatively high electricity tariff. Because the thermal production of the hybrid plant surpassed the electrical production by nearly fivefold (see Figure 3), the savings generated by heat production prevailed upon the ones generated by electricity. Therefore, the economic performance of the hybrid plant mainly depends on the fuel to be displaced and on its price. Nevertheless, as will be further presented in this study, the added value of electricity generation is relevant in this technology, and it can be assessed from the economic perspective and strictly depends on the local prices of electricity. 
Table 3. Economic metrics of the hybrid plant and conventional system, respectively (Source: Author's own calculation).

\begin{tabular}{|c|c|c|}
\hline Parameters & Hybrid Plant & Conventional System \\
\hline Initial investment cost $(\mathrm{Co}), \mathrm{USD}$ & $\$ 210,889$ & $\$ 29,000$ \\
\hline Hybrid receivers cost ${ }^{1}$, USD & $\$ 20,534$ & - \\
\hline Energetics price ratio, $C_{e} / C_{f}$ & 5.68 & \\
\hline Annual savings (Cs), USD & $\$ 7288$ & - \\
\hline Payback time $(P B T)$, years & 19.23 & - \\
\hline Life cycle savings (LCS), USD & $\$ 109,739$ & - \\
\hline $\mathrm{LCOH}_{e q}, \mathrm{USD} / \mathrm{kWh}$ & 0.065 & 0.067 \\
\hline$L C O E_{e q} \mathrm{USD} / \mathrm{kWh}$ & 0.085 & 0.09 \\
\hline
\end{tabular}

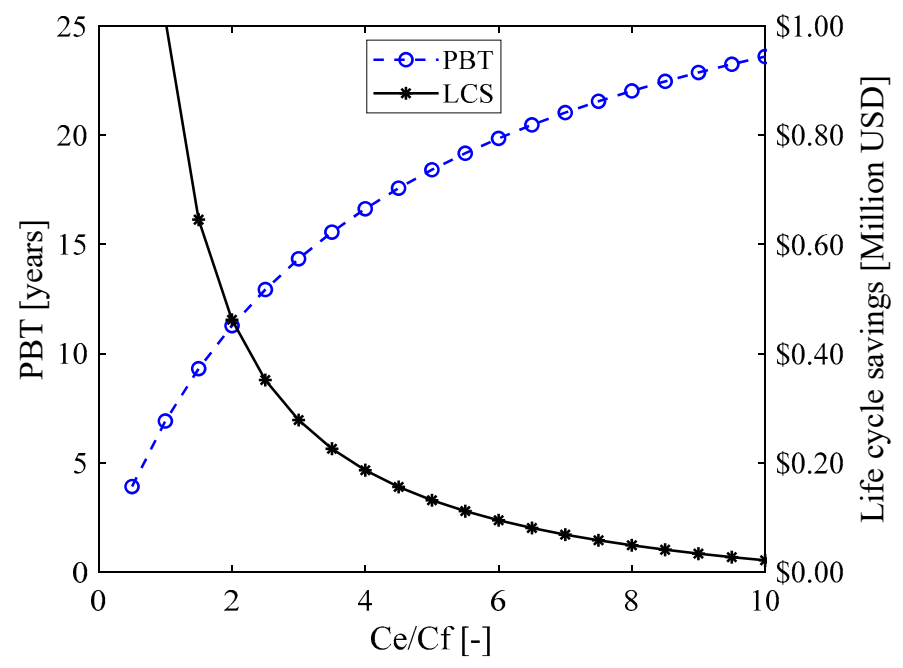

Figure 7. Payback time and life cycle savings versus the energetics price ratio $\left(C_{e} / C_{f}\right)$ (Source: Author own calculation).

The annual monetary savings and environmental benefits owing to the clean energy production of the hybrid solar plant are shown in Figure 8. Notably, the hybrid plant can annually generate 7183 USD of monetary savings, accounting for the heat and electricity generation. The majority of the monetary savings is attributed to the heat generation by the solar plant, accounting for $62.9 \%$ of the total. Nevertheless, the savings attained by electricity generation of the plant also represent a significant quota, despite the fact that the hybrid plant produced a diminished amount of power in comparison with that of heat.

The specific monetary savings, defined as the ratio between the annual savings and energy production, show that heat generation can save 18.78 USD per thermal MWh generated. Simultaneously, the specific savings represented by electricity generation are 60.83 USD per electric MWh, which is 3.23 times that of thermal generation. From Table 1, it is evident that the unit energy cost of electricity is five times that one of natural gas, explaining why the savings associated with electricity generation outweigh those associated with heat generation. It is one of the reasons that the hybridization of thermal technologies can achieve higher monetary savings than solar thermal collectors, even when the electricity tariff is higher than the fuel cost. 

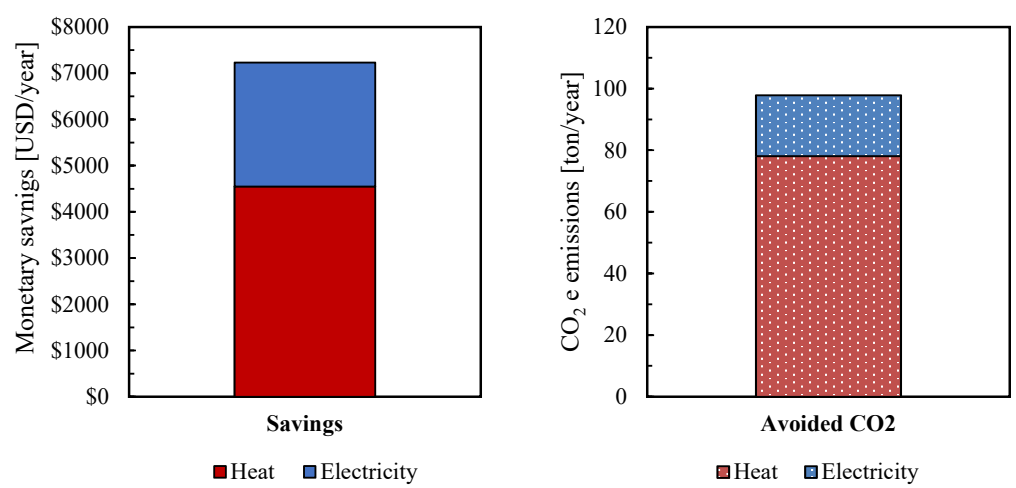

Figure 8. Annual monetary savings (left) and avoided $\mathrm{CO}_{2 \mathrm{e}}$ emissions (right) (Source: Author own calculation).

To evaluate the present value of generating a unit of energy and to have a normalized frame of reference for comparison purposes between various technologies, the levelized cost of energy is widely used in the energy sector. In this study, two approaches were used to calculate and analyze this parameter: (1) the electricity integrated LCOE proposed by Wang et al. [5] and (2) the heat integrated $\mathrm{LCOH}$ proposed in this study. The former involves determining the electricity equivalent of heat production by using a natural gas power plant with an efficiency of 0.55 . This approach may imply that the fuel displaced owing to the thermal production of the hybrid plant, will now be used for electricity generation. This can contradict the main target (i.e., fossil fuel consumption reduction) of the studied technology. Moreover, the conversion factor considered in the previously mentioned study [5] resembles fuel to electrical energy conversion, rather than thermal to electricity generation. Therefore, the equivalent heat $\mathrm{LCOH}_{e q}$ approach has been considered in this study. This latter approach considers the conversion efficiency from electricity to heat to be 1 . This conversion implies that the electricity generated by the hybrid solar plant can be used for water heating by using ER. We consider that this perspective achieves more objective results within the fuel displacement context of the technology in comparison with $L C O E_{\text {eq }}$.

Table 3 presents the $L C O E_{e q}$ and $L C O H_{e q}$ values calculated for this case study. The $L C O H_{e q}$ value is $23.5 \%$ lower than $L C O E_{\text {eq }}$, possibly making the proposed hybrid technology highly competitive if the economic evaluation is based on $L C O H_{e q}$. Nevertheless, $L C O H_{e q}$ is only $3 \%$ lower than the $L C O H$ of the conventional natural gas boiler. Furthermore, if the electricity to heat conversion factor for the $\mathrm{LCOH}_{\text {eq }}$ calculation is considered to be 3 [33], which is the COP of a conventional heat pump, $L C O H_{e q}$ can reach $0.045 \mathrm{USD} / \mathrm{kWh}$, which represents a reduction of $31 \%$ from the case with ER $(0.065 \mathrm{USD} / \mathrm{kWh})$.

Because the final price of the hybrid receptor has not been yet established, a sensibility analysis of the levelized cost of energy as a function of the receptor fractional cost (RFC) was conducted. From Figure 9, we can notice that both $L C O E_{e q}$ and $L C O H_{e q}$ ER increase as the receptor fractional price increases. Nevertheless, $L C O H_{e q}$ ER increases at a slower pace (USD 0.022 per RFC) than $L C O E_{e q}$ (USD 0.03 per RFC). This difference is attributed to the following reasons: (1) the savings associated with heat production prevail over those associated with electricity, (2) the $\mathrm{LCOH}_{e q}$ approach considers that electricity transforms into heat with a conversion factor of 1 . If the heat pump COP is considered for the $L C O H_{e q}$ calculation ( $L C O H_{e q} \mathrm{HP}$ ), the slope of the curve decreases to USD 0.014 per RFC. From these results, we can conclude that to have a levelized cost of heat $\left(\mathrm{LCOH}_{e q} \mathrm{ER}\right)$ lower than the one obtained with a conventional system, the hybrid receptor cost should not be higher than $22 \%$ of the cost of the parabolic trough reflectors. 


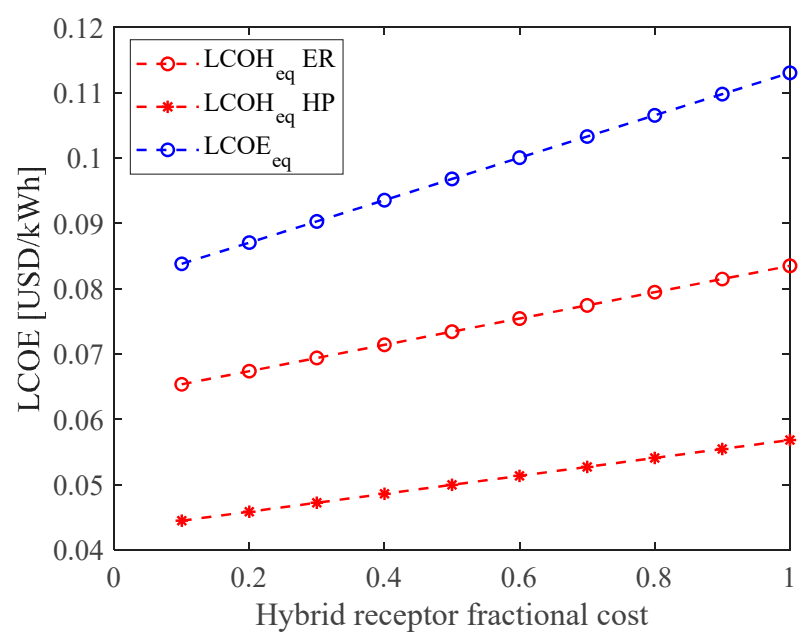

Figure 9. Levelized cost of electricity (LCOE) and levelized cost of heat (LCOH) as a function of the hybrid RFC (Source: Author's own calculation).

Notably, in this study, none incentives based on the positive environmental impact of the installation of the proposed technology were considered. This presents an opportunity to enhance the economic performance of the solar hybrid plant if carbon taxes or other local incentives, like the ones presented in [34,35], are considered.

Figure 8 evaluates the GHG emission abatement potential of the hybrid plant. The annual reduction in the $\mathrm{CO}_{2} \mathrm{e}$ emissions can reach 97.9 metric tons, the majority of which, i.e., 80\% (78.14 tons), is associated with the displacement of natural gas for heat generation. The $\mathrm{CO}_{2}$ e emission abatement potential achieved by the proposed hybrid plant is $77.87 \mathrm{~kg} \mathrm{CO}_{2} \mathrm{e} / \mathrm{m}^{2}$, which is equivalent to taking nearly 21 passenger vehicles out of the streets every year [36]. If we consider the lifespan of the hybrid plant to be 25 years, its application into the sports center can avoid the emission of 2446 metric tons of $\mathrm{CO}_{2} \mathrm{e}$.

Both the economic and environmental impacts of the proposed hybrid plant can be more significant when the thermal generation displaces other fuels including diesel, fuel oil, or LPG. Therefore, further studies should be performed in other Mexican cities where other fuels are utilized for heat generation and where higher insolation levels are available.

\section{Conclusions}

The techno-economic performance of a solar hybrid plant in a sports and wellness center building of a university college in Monterrey was studied. A transient simulation developed in TRNSYS, coupled with a steady-state model, was used. The results showed that the thermal demand, i.e., DHW and pool heating, could be partially covered by the proposed solar hybrid system. The solar fraction could achieve up to $72 \%$ and $24 \%$ during the summer and winter seasons, respectively. The hot water storage capacity and the constant thermal demands ensure that the temperature of the PV cells remains relatively low. Nevertheless, further improvements in the design and operations should be pursued to decrease the temperature levels, especially during the summer season.

Regarding the economic analysis, despite the good energy performance of the proposed hybrid plant, the evaluated economic parameters (PBT and LCC) were not sufficiently encouraging. Notably, the hybrid plant system is yet a costly alternative for heat and power generation, leading to a $P B T$ of nearly 19 years, considering the local tariffs and technology costs (hybrid RFC of 0.2 from the parabolic trough receptor costs). The PBT lasts longer in comparison with other clean energy generation systems, including PV panels or solar thermal collectors, whose PBTs might lie between 3 and 8 years in Mexico. The long PBT is mainly attributed to the reduced local price of natural gas in Monterrey and to the 
subsidized electrical commercial tariff scheme in Mexico. The ratio of the prices of electricity and natural gas should be low $(<2.0)$ to achieve satisfactory PBTs and LCCs.

This study proposed a new approach for evaluating the levelized cost of energy in hybrid solar collectors, wherein the equivalent heat was calculated considering the conversion factor from electricity to heat of 1 . This new approach allows for a more objective evaluation of hybrid collectors than those presented in previous studies, provided that the purpose of this technology is the reduction in the fossil fuel consumption. The $\mathrm{LCOH}_{e q}$ obtained $(0.065 \mathrm{USD} / \mathrm{kWh})$ was almost equal to the $\mathrm{LCOH}$ of a natural gas-fired boiler $(0.067 \mathrm{USD} / \mathrm{kWh})$, possibly indicating that the hybrid technology is a better alternative than conventional systems. Moreover, the sensibility analysis showed that $L C O H_{e q}$ presented a lower dependence on the cost of the hybrid receptor in comparison with $L C O E_{e q}$.

The LCPV/T technology presented in this study still under development, hence further efforts should be made to reduce the total component and installation costs to be more competitive in comparison with conventional technologies. Additionally, higher fuel prices and local incentives would make the proposed technology more attractive for investment. Notably, if the low economic performance of the proposed plant is not a dealbreaker, the proposed hybrid solar technology has an excellent $\mathrm{CO}_{2} \mathrm{e}$ emission reduction potential. As an evidence, in this study, the hybrid plant could achieve a specific $\mathrm{CO}_{2} \mathrm{e}$ emission reduction of $77.87 \mathrm{~kg} \mathrm{CO}_{2} \mathrm{e}$ per square meter of the required installation area. This could make the proposed technology relevant particularly in applications wherein $\mathrm{CO}_{2}$ emission abatement is the main goal.

It is important to mention that for existing solar thermal plants based on the parabolic trough technology studied in this article, the hybridization of the solar collector can be considered. This will lead to a better economic performance of the plant, since the already existing infrastructure can be used, and only the costs of the hybrid receptor replacement should be taken into account.

Author Contributions: All authors conducted this study. Conceptualization, I.A.-P.; Methodology, I.A.-P., C.R.-S. and M.G.R.; investigation, I.A.-P. and C.I.-R.; data curation, I.A.-P. and M.G.-R.; writing-original draft preparation, I.A.-P., C.R.-S. and M.G.-R.; writing-review and editing, I.A.-P., C.R.-S. and M.G.-R.; supervision, C.R.-S. and M.G.-R.; project administration, C.R.-S. and M.G.-R.; funding acquisition, C.R.-S. and M.G.-R. All authors have read and agreed to the published version of the manuscript.

Funding: This research was funded by the Consejo Nacional de Ciencia y Tecnología (CONACYT) and the Secretaría de Energía (SENER) under the Energy Sustainability Grants/Project No 291590.

Acknowledgments: The authors would like to thank the Mexican company Inventive Power for providing relevant information for this research. I. Acosta-Pazmiño acknowledges the support provided by the Mexican Science and Technology Council (CONACYT) given through its doctoral scholarship program.

Conflicts of Interest: The authors declare no conflict of interest.

\section{Nomenclature and Subscripts}

$\begin{array}{ll}\text { Nomenclature } & \\ A & \text { Area }\left(\mathrm{m}^{2}\right) \\ C_{r} & \text { Concentration ratio } \\ C_{L H V f} & \text { Fuel low heating value }(\mathrm{kJ} / \mathrm{kg}) \\ c p & \text { Thermal specific capacity }\left(\frac{\mathrm{kJ}}{\mathrm{kg}}{ }^{\circ} \mathrm{C}\right) \\ C_{E} & \text { Electricity savings (USD) } \\ C_{F} & \text { Fuel savings (USD) } \\ C_{S} & \text { Total savings (USD) } \\ d & \text { Discount rate } \\ E & \text { Electricity }(\mathrm{kWh}) \\ E P & \text { Electricity price }(\mathrm{USD} / \mathrm{kWh}) \\ D & \text { Derate } \\ F_{R} & \text { Collector heat removal factor } \\ F \prime & \text { Collector efficiency factor } \\ F P & \text { Fuel price }\left(\mathrm{USD} / \mathrm{m}^{3}\right) \\ F_{v} & \text { Fuel volume }\left(\mathrm{m}^{3}\right)\end{array}$

$\begin{array}{ll}\text { Subscripts } & \\ a & \text { Aperture } \\ a m b & \text { Ambient } \\ b & \text { Boiler } \\ e & \text { Electrical } \\ f & \text { Fuel } \\ i & \text { Intermediate } \\ L C P V T & \text { Low concentrating PV/T } \\ P V & \text { Photovoltaic cells } \\ P V_{r} & \text { Photovoltaic reference } \\ r & \text { Receiver } \\ t h & \text { Thermal } \\ O \& M & \text { Operation and maintenance } \\ \text { Greek Symbols } & \\ \alpha & \text { absorptance } \\ \eta & \text { Efficiency }\end{array}$




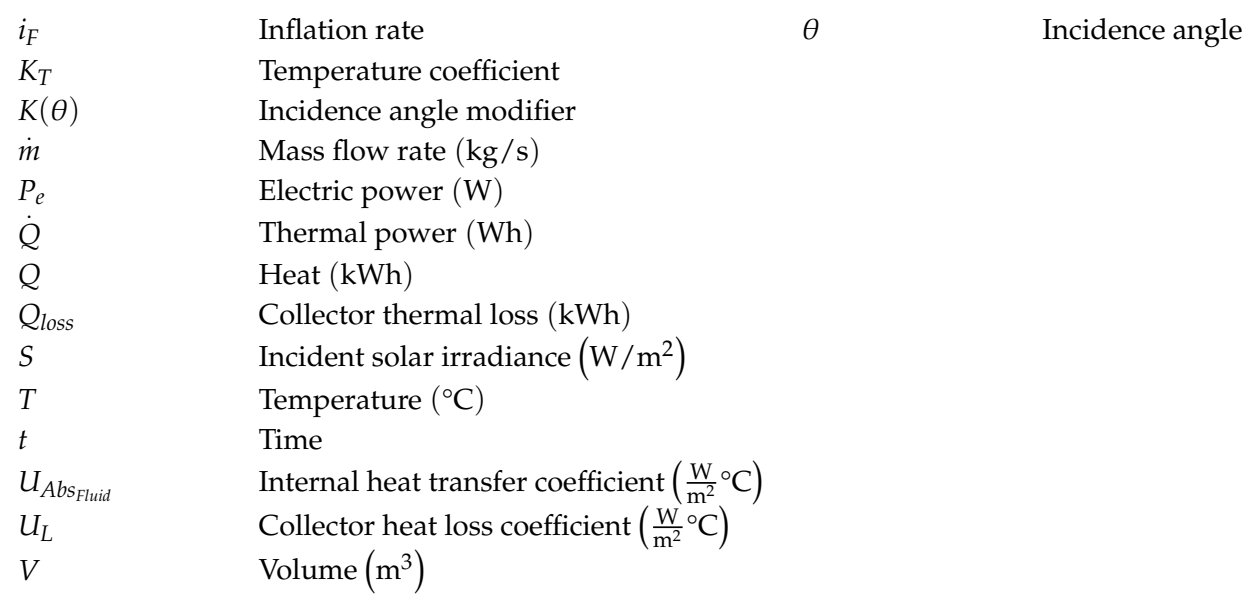

\section{References}

1. Sotehi, O.; Chaker, A.; Maalouf, C. Hybrid PV/T water solar collector for net zero energy building and fresh water production: A theoretical approach. Desalination 2016, 385, 1-11. [CrossRef]

2. Fuentes, M.; Vivar, M.; de la Casa, J.; Aguilera, J. An experimental comparison between commercial hybrid PV-T and simple PV systems intended for BIPV. Renew. Sustain. Energy Rev. 2018, 93, 110-120. [CrossRef]

3. Yang, L.; Heng, Z.; Haiping, C.; Han, Y.; Fei, Y. Simulating and experimental research on a low-concentrating PV/T triple-generation system. Energy Convers. Manag. 2019, 199, 111942. [CrossRef]

4. Herrando, M.; Pantaleo, A.M.; Wang, K.; Markides, C.N. Solar combined cooling, heating and power systems based on hybrid PVT, PV or solar-thermal collectors for building applications. Renew. Energy 2019, 143, 637-647. [CrossRef]

5. Wang, K.; Herrando, M.; Pantaleo, A.M.; Markides, C.N. Technoeconomic assessments of hybrid photovoltaic-thermal vs. conventional solar-energy systems: Case studies in heat and power provision to sports centres. Appl. Energy 2019, 254, 113657. [CrossRef]

6. Behzadi, A.; Arabkoohsar, A.; Yang, Y. Optimization and dynamic techno-economic analysis of a novel PVT-based smart building energy system. Appl. Therm. Eng. 2020, 181, 115926. [CrossRef]

7. Brottier, L.; Bennacer, R. Thermal performance analysis of 28 PVT solar domestic hot water installations in Western Europe. Renew. Energy 2020, 160, 196-210. [CrossRef]

8. Braun, R.; Haag, M.; Stave, J.; Abdelnour, N.; Eicker, U. System design and feasibility of trigeneration systems with hybrid photovoltaic-thermal (PVT) collectors for zero energy office buildings in different climates. Sol. Energy 2019, 196, 39-48. [CrossRef]

9. Zhou, C.; Ruobing, L.; Jili, Z. Optimization Design Method and Experimental Validation of a Solar PVT Cogeneration System. Energies 2017, 10, 1281. [CrossRef]

10. Obalanlege, M.A.; Mahmoudi, Y.; Douglas, R.; Ebrahimnia-Bajestan, E.; Davidson, J.; Bailie, D. Performance assessment of a hybrid photovoltaic-thermal and heat pump system for solar heating and electricity. Renew. Energy 2020, 148, 558-572. [CrossRef]

11. Del Amo, A.; Martínez-gracia, A.; Pintanel, T.; Bayod-rújula, A.A.; Torné, S. Analysis and optimization of a heat pump system coupled to an installation of PVT panels and a seasonal storage tank on an educational building. Energy Build. 2020, 226, 110373. [CrossRef]

12. Abdul-ganiyu, S.; Quansah, D.A.; Ramde, E.W.; Seidu, R.; Adaramola, M.S. Investigation of Solar Photovoltaic-Thermal ( PVT) and Solar Photovoltaic ( PV ) Performance: A Case Study in Ghana. Energies 2020, 13, 2701. [CrossRef]

13. Guarini, M.R.; Morano, P.; Sica, F. Integrated ecosystem design: An evaluation model to support the choice of eco-compatible technological solutions for residential building. Energies 2019, 12, 2659. [CrossRef]

14. U.S. Energy Information Administration. International Energy Outlook 2019; U.S. Energy Information Administration: Washington, DC, USA, 2019.

15. Knaack, J.; Oropeza, M.; Potowski, K.; Quiñones, A. Calor Solar Para la Industria México. Available online: https://www.solar-payback.com/wp-content/uploads/2017/07/Solar-Heat-for-IndustrySolar-Payback-April-2017.pdf (accessed on 26 September 2019). 
16. Acosta, P.I.P. Caracterización y Evaluación de un Sistema Hibrido Fotovoltaico/Térmico Basado en un Concentrador Parabólico Lineal; Tecnológico de Monterrey: Monterrey, Mexico, 2016.

17. Duffie, J.A.; Beckman, W.A. Solar Engineering of Thermal Processes; Wiley: Hoboken, NJ, USA, 2013; ISBN 9780470873663.

18. Florschuetz, L.W. Extension of the Hottel-Whillier model to the analysis of combined photovoltaic/thermal flat plate collectors. Sol. Energy 1979, 22, 361-366. [CrossRef]

19. Gaul, H.; Rabl, A. Incidence-Angle Modifier and Average Optical Efficiency of Parabolic Trough Collectors. J. Sol. Energy Eng. 1980, 102, 16-21. [CrossRef]

20. Bernardo, L.R.; Perers, B.; Håkansson, H.; Karlsson, B. Performance evaluation of low concentrating photovoltaic/thermal systems: A case study from Sweden. Sol. Energy 2011, 85, 1499-1510. [CrossRef]

21. Comisión Reguladora de Energía Índice de Referencia Nacional de Precios de Gas Natural al Mayoreo (IPGN). Available online: https://www.cre.gob.mx//IPGN/index.html (accessed on 9 May 2020).

22. Comisión Federal de Electricidad. Tarifas Gran Demanda Media Tensión Horaria (GDMTH). Available online: https:/app.cfe.mx/Aplicaciones/CCFE/Tarifas/TarifasCRENegocio/Tarifas/GranDemandaMTH.aspx (accessed on 9 May 2020).

23. IEA International Energy Agency. Industrial Combustion Boilers; CRC Press: Boca Raton, FL, USA, 2010.

24. Kalogirou, S.A. Solar Energy Engineering: Processes and Systems, 2nd ed.; EBSCO Publishing: Ipswich, MA, USA, 2014; ISBN 9780123972705.

25. Kassem, Y. Solar Energy Potential and Feasibility Study of a 10MW Grid-connected Solar Plant in Libya. Eng. Technol. Appl. Sci. Res. 2020, 10, 5358-5366.

26. Trading Economics Mexico Interest Rate|2005-2020 Data. Available online: https:/tradingeconomics.com/ mexico/interest-rate (accessed on 12 October 2020).

27. Riggs, B.C.; Biedenharn, R.; Dougher, C.; Ji, Y.V.; Xu, Q.; Romanin, V.; Codd, D.S.; Zahler, J.M.; Escarra, M.D. Techno-economic analysis of hybrid PV/T systems for process heat using electricity to subsidize the cost of heat. Appl. Energy 2017, 208, 1370-1378. [CrossRef]

28. Wang, K.; Pantaleo, A.M.; Herrando, M.; Faccia, M.; Pesmazoglou, I.; Franchetti, B.M.; Markides, C.N. Spectral-splitting hybrid PV-thermal (PVT) systems for combined heat and power provision to dairy farms. Renew. Energy 2020, 159, 1047-1065. [CrossRef]

29. Ramos, A.; Chatzopoulou, M.A.; Guarracino, I.; Freeman, J.; Markides, C.N. Hybrid photovoltaic-thermal solar systems for combined heating, cooling and power provision in the urban environment. Energy Convers. Manag. 2017, 150, 838-850. [CrossRef]

30. U.S. Department of Energy. Electric Resistance Heating. Available online: https://www.energy.gov/ energysaver/home-heating-systems/electric-resistance-heating (accessed on 14 September 2020).

31. Secretaría de Energía Sistema de Información Energética. Available online: http://sie.energia.gob.mx/ (accessed on 20 May 2020).

32. IPCC. Emission Factor Database. Available online: https://www.ipcc-nggip.iges.or.jp/EFDB/main.php (accessed on 14 August 2020).

33. U.S. Department of Energy. Heat Pump Water Heaters. Available online: https://www.energy.gov/ energysaver/water-heating/heat-pump-water-heaters (accessed on 14 September 2020).

34. Herrando, M.; Ramos, A.; Freeman, J.; Zabalza, I.; Markides, C.N. Technoeconomic modelling and optimisation of solar combined heat and power systems based on flat-box PVT collectors for domestic applications. Energy Convers. Manag. 2018, 175, 67-85. [CrossRef]

35. Rashid, K.; Safdarnejad, S.M.; Ellingwood, K.; Powell, K.M. Techno-economic evaluation of different hybridization schemes for a solar thermal/gas power plant. Energy 2019, 181, 91-106. [CrossRef]

36. United States Environmental Protection Agency. Greenhouse Gas Equivalencies Calculator. Available online: https://www.epa.gov/energy/greenhouse-gas-equivalencies-calculator (accessed on 4 August 2020).

Publisher's Note: MDPI stays neutral with regard to jurisdictional claims in published maps and institutional affiliations. 